\title{
SÜRK PEYNİRİNDEN İZOLE EDİLEN KÜFLERİN PCR YÖNTEMİYLE TANIMLANMASI
}

\author{
Yusuf Esen $^{1 *}$, Özlem Turgay ${ }^{2}$ \\ ${ }^{1}$ Gıda Teknolojisi Programı, Teknik Bilimler Meslek Yüksekokulu, Ardahan Üniversitesi, Ardahan, Türkiye \\ ${ }^{2}$ Gıda Mühendisliği Bölümü, Mühendislik Fakültesi, Kahramanmaraş Sütçü İmam Üniversitesi, Kahramanmaraş, \\ Türkiye
}

Geliş / Received: 24.11.2021; Kabul / Accepted: 21.01.2022; Online bask1 / Published online: 17.02.2022

Esen, Y., Turgay, Ö. (2022). Sürk peynirinden izole edilen küflerin PCR yöntemiyle tanımlanması. GID $A$ (2022) 47(1) 136-146 doi: 10.15237/gida.GD21144

Esen, Y., Turgay, Ö. (2022). Identification of molds isolated from sürk cheese by PCR method. GIDA (2022) 47(1) 136-146 doi: 10.15237/gida.GD21144

\section{ÖZ}

$\mathrm{Bu}$ çalışmada olgunlaşmış Sürk peyniri örneklerinde baskın olan küf mikrobiyotasının büyük ölçüde tanımlanması gerçekleştirilmiştir. Çalışmada analizleri yapılan Sürk örnekleri, Hatay-Antakya piyasasındaki 36 farklı iş yerinden tesadüfi olarak temin edilmiştir. Olgunlaşmış Sürklerden izole edilen küflerdeki ITS bölgesinden faydalanılarak tanımlamaları gerçekleştirilmiştir. Örneklerden elde edilen 67 izolatın genetik identifikasyonu sonucunda 9 farklı tür tanımlanmıştır. Bu küf türleri Sürk örneklerindeki baskınlık oranlarına göre sirasiyla Penicillium commune (\%55.5), Alternaria alternata (\%33.3), Cladosporium cladosporioides (\%30.5), Epicoccum nigrum (\%16,6), Aspergillus flavus (\%16,6), Penicillium chrysogenum (\%13.8), Aspergillus niger var. awamori (\%11.1), Phoma sojicola $(\% 8,3)$ ve Bipolaris tetramera (\%2.7)'dır. Bu çalışma, olgunlaşmış Sürk peynirinin küf mikrobiyotasının genetik olarak tanımlandığ ilk araştırmadır.

Anahtar kelimeler: Olgunlaşmış Sürk peyniri, küf, mikrobiyota, PCR.

\section{IDENTIFICATION OF MOLDS ISOLATED FROM SÜRK CHEESE BY PCR METHOD}

\begin{abstract}
In this study, a large-scale identification of the predominant mold microbiota in ripened Surk samples was achieved. Surk cheese samples analyzed in the study were obtained randomly from 36 different cheese shops in the Hatay-Antakya market. Identifications were carried out using the ITS region in the molds isolated from ripened Surks. As a result of the genetic identification of 67 isolates obtained from the samples, 9 different strains were identified. According to the dominance rates of these mold strains in Surk samples, Penicillium commune (55.5\%), Alternaria alternata (33.3\%), Cladosporium cladosporioides (30.5\%), Epicoccum nigrum (16.6\%), Aspergillus flavus (16.6\%), Penicillium chrysogenum (13.8\%), Aspergillus niger var. awamori (11.1\%), Phoma sojicola (8.3\%) and Bipolaris tetramera $(2.7 \%)$. This is the first study in which the mold microbiota of ripened Surk cheese has been genetically identified. Keywords: Ripened Surk cheese, mold, microbiota, PCR.
\end{abstract}

${ }^{*}$ Yazışmalardan sorumlu yazar / Corresponding author;

$\triangle$ yusufesen@ardahan.edu.tr

(2) (+90) 4782117575

国:(+90) 4782117544

Yusuf Esen; ORCID no: 0000-0003-1173-0677

Özlem Turgay; ORCID no: 0000-0003-2286-833X 


\section{GİRİ̧̧}

Sürk, Arapça'da çökelek anlamına gelmektedir. Mahreç işaretinde belirtildiği üzere, üretimde kullanılacak çökeleğin elde edilebilmesi için öncelikle sütten yoğurt üretilmesi gerekmektedir. Daha sonra üretilen yoğurt 1-2 gün oda sıcaklığında $\left(23-25^{\circ} \mathrm{C}\right)$ ekşitilir. Ardından yoğurda 1:1 oranında su ilave edilerek ayran yapilır. Elde edilen ayran çalkalanır ve yayık üzerinde kalan yağ üstten alınır. Alttaki yağsız ayran kaynatılır ve soğuduktan sonra tülbent ile süzülür. Bu işlemle elde edilen çökelek, Sürk peyniri üretiminde kullanılmaktadır. Bir süt ürünü olan Sürk peynirinin üretimi, çökeleğe belirli baharatların eklenmesi, yoğurma, şekillendirme ve olgunlaştırma aşamalarından oluşmaktadır. Sürk peyniri yapımında kullanılan baharat karışımında belirli oranlarda kekik, yenibahar, karanfil, mahlep, hindistan cevizi, kimyon, tarçın, zencefil, fesleğen, rezene, çörek otu, pul biber ve kişniş bulunmaktadır. Bunlara ek olarak tuz ve sarımsak da eklenebilmektedir. Konik olarak hazırlanan Sürk peyniri karışımı taze tüketilmekte veya isteğe göre 1-6 ay olgunlaştırrlarak tüketilmektedir (Anonymous, 2018; Güler, 1999).

Sürk peyniri, özellikle Hatay'da ve Türkiye'nin Doğu Akdeniz bölgesinde, Suriye'de, Lübnan'da ve tüm Orta Doğu'da bilinmekte ve tüketilmekte olan bir süt ürünüdür. Fakat Türkiye dışındaki coğrafyalarda farklı isimlerle anılmaktadır. Ülke ve bölgeye bağlı olarak shanklish, shinklish, shankleesh veya sorke isimleriyle bilinmektedir (Addas, 2013; Serhan ve Mattar, 2013; Toufeili vd., 1995). Bahsi geçen coğrafyaların yanı sıra Lübnanlı göçmenler sayesinde (Lübnan sivil savaşı sebebiyle göçenler) Arjantin'in Corrientes bölgesinde de bilinen bir süt ürünü haline gelmiştir (Patino vd., 1999). Ayrıca 2018 yilı başlarında Türk Patent Enstitüsü tarafindan Sürk peynirine coğrafi işaret verilmiştir (Anonymous, 2018).

Küfler her türlü gıdada üreyebildikleri gibi birçok peynir de doğal olarak gelişmekte ya da özellikle geliştirilmektedirler. Türkiye'de ve dünyanın çoğu ülkesinde peynirlerde geliştirilen küfler vasıtasıyla olgunlaştırılan küflü peynir çeşitleri bulunmaktadır. Rokfor, Çedar ve Parmesan peynirleri ile Konya küflü peyniri, Erzurum göğermiş peyniri, Kars gravyer peyniri ve Divle tulum peyniri bunlardan en çok bilinenleridir. Ancak küf gelişimi, çürüme, toksinler, kötü tatlar, renk bozulması şeklinde ortaya çıkabilen çok farklı çeşitlerde bozulmalara da sebep olabilmektedirler (Erdogan vd., 2003).

Fakat bu olumsuzluklara rağmen küfler peynir mikrobiyotasının önemli bir parçası olarak her zaman karşımıza çıkmaktadır. Küflerin peynir üretiminde birincil starter olarak kullanılmasindan ziyade ikincil starter kültür olarak kullanıldığ bilinmektedir (Cantor vd., 2017). Geleneksel metotlarla üretilen birçok peynir çeşidinde uzun olgunlaşma sürelerinden ötürü ürünlerin yüzeyinde küfler gelişmektedir. Küflerin ürettiği enzimlerin, proteoliz yetenekleri sayesinde aroma gelişimine büyük fayda sağlamalarından ve peynir kalitesini arttırmalarından ötürü, küf gelişimi olgunlaşmıs peynirlerde istenen bir durumdur. Fakat olgunlaştırma periyodu boyunca nem, $\mathrm{pH}$, sıcaklık gibi ortam şartlarının kontrolsüz olması mikotoksin üretebilen küflerin de gelişmesine sebep olabilmektedir. $\mathrm{Bu}$ nedenle peynirlerin olgunlaştırıldığı ortam koşullarının kontrol altında tutulması oldukça önem arz etmektedir (Cantor vd., 2017; Delgado vd., 2016). Aroma ve tekstürle ilgili faydalarının yanında, bazı küfler antifungal karakteristiklere sahip peptidler ve proteinler (Anti Fungal Protein-AFP) üretebilmektedirler. $\mathrm{Bu}$ sayede mikotoksin üretme yeteneği olan küflerin ve istenmeyen bazı mayaların gelişiminin inhibisyonu açısından biyokontrol imkânı sağlamaktadırlar (Hegedüs ve Marx, 2013).

Bu çalışmada, Hatay-Antakya piyasasından temin edilen Sürk peyniri örneklerinin baskın küf mikrobiyotasının tanımlanması amacıyla kültürel yöntemlerle birlikte PCR metodu kullanılmıştır. $\mathrm{Bu}$ amaçla önce Sürk peyniri örneklerinden alınan numunelerin küf yükleri PDA ve MEA besiyerleri kullanılarak belirlenmiştir. Daha sonra morfolojik olarak farklı olan tüm küf kolonileri saflaştırılmış ve bu kolonilerden DNA izolasyonlanı yapılmıştır. Son olarak elde edilen DNA izolatlarn ITS primerleri kullanilarak PCR, elektroforez jelde yürütme ve sekans analizine tabi tutulmuştur. Elde edilen gen dizileri BLAST algoritmasi 
kullanılarak değerlendirilmiş ve tanımlamalar yapilmıştır. Bu çalışma Sürk'te bulunan küf mikrobiyotasının belirlenmesi amacıyla yapılmış olan ilk araştırmadır.

\section{MATERYAL ve YÖNTEM}

\section{Materyal}

Çalışmada kullanılan 36 adet Sürk peyniri örneği, Hatay-Antakya piyasasından temin edilmiştir. Örnekler satış noktalarından piyasaya sunulduğu şekilde alınarak steril poşetler içerisinde ve soğutuculu termosla laboratuvara getirilmiştir. Analizler gerçekleştirilene kadar ve tüm çalışma boyunca Sürk peyniri örnekleri $+4^{\circ} \mathrm{C}^{\prime}$ de buzdolabında bekletilmiştir.

\section{Yöntem}

\section{Küf mikrobiyotasının identifikasyonu Örneklerin Analize Hazırlanmas1}

Örneklerin tanımlamaya hazırlanmasında kullanılan yöntem seyreltme plaka tekniğidir. Dilüsyonlar diğer mikrobiyolojik analizlere göre hazırlanmış olsa da küf sporları çok kolay dibe çöktükleri için ekim mümkün olduğu kadar kısa sürede yapılmıştır (Yoltaş, 2007). Analizler Sürk peyniri örneklerinin dış ve iç kısımlarından eşit miktarda karıştırılarak gerçekleştirilmiştir. Dış kısımlarda yoğun küflenme gözlendiğinden ve tüm farklı morfolojiye sahip koloniler saflaştırıldığından dolayı örneklendirme bu şekilde yapılmıştır.

Piyasadan temin edilen Sürk peyniri örneklerinin her birinden $10 \mathrm{~g}$ alınarak aseptik koşullar altında $90 \mathrm{ml}$ steril Tween 80’li \%0.85'lik $\mathrm{NaCl}$ çözeltisi içerisine alınarak 1/10 oranında seyreltilmiştir. Bu halde 1-2 saat bekletildikten sonra homojenizasyon için çalkalayıcıda $30 \mathrm{~d}$ çalkalanarak, 9'ar $\mathrm{ml}$ steril $\% 0.85^{\prime}$ lik $\mathrm{NaCl}$ çözeltisi ile $10^{-2}-10^{-6^{\prime}} 1 \mathrm{lk}$ dilüsyonlar hazırlanmış ve $10^{-4}, 10^{-5}$ ve $10^{-6} \mathrm{l} l \mathrm{k}$ seyreltmelerden paralelli olacak şekilde steril standart petri kaplarına 1'er ml dökme ekim yöntemi ile ekim yapılmıştır. Genel fungal floranin belirlenmesi için RBCA (Rose Bengal Chloramphenicol Agar) besiyeri, ozmofilik türlerin belirlenmesi için ise MEA $+\% 40$ sakkaroz (Malt Extract Agar) ortamlar1 kullanılmıstır. Dört günlük inkübasyondan sonra petrilerde oluşan küf kolonileri makromorfolojik farklılıklarına göre izole edilmişlerdir. $\mathrm{Bu}$ işlem sonrasında ise küflerin tanılamasına geçilmiştir (Anonymous, 2012).

\section{İzolatların Tanılanması}

İzole edilen küfler ilk önce cins düzeyinde tayinlerinin, yapılabilmesi için MEA ve PDA ortamlarına inoküle edilmişlerdir. $25^{\circ} \mathrm{C}$ 'de 5-7 gün inkübasyondan sonra koloniler makroskobik ve mikroskobik olarak incelenmiş ve cins düzeyinde tanımlanmışlardır (Domsch vd., 1995; Hasenekoğlu, 1991; Klich, 2002; Pitt, 2000).

\section{DNA İzolasyonu}

DNA izolasyonu amaciyla Doyle ve Doyle (1987) tarafindan tavsiye edilen CTAB (cetyltrimethyl amonium bromide) Metodu modifiye edilerek kullanılmıştır. İlk olarak 1.5 mL'lik tüplere kolonilerden örnekler aktarılmıştır. Üzerlerine 500 $\mu \mathrm{L}$ CTAB Buffer eklendikten sonra $2 \mathrm{~d}$ boyunca vortex karıştırıcı yardımıyla karıştırılmıştır. Daha sonra 30 dakikada bir karıştırılmak üzere $65^{\circ} \mathrm{C}^{\prime}$ lik su banyosunda 1,5 saat inkübasyona bırakılmıştır. İnkübasyondan sonra tüplere $233 \mu \mathrm{L}$ izopropanol ilave edilerek $65^{\circ} \mathrm{C}$ lik su banyosunda $15 \mathrm{~d}$ bekletilmiştir. Bu süre sonunda $1 \mathrm{~d}$ boyunca ters düz edilerek karıştırılmıştır. Karıştırılan tüpler, $500 \mu \mathrm{L}$ kloroform:izoamil alkol (24:1) ilavesinden sonra tekrar $65^{\circ} \mathrm{C}^{\prime}$ lik su banyosunda $5 \mathrm{~d}$ bekletilmiştir. Tüpler bekletildikten sonra 14000 devir/d'da 5 d boyunca santrifüj edilmişlerdir. $\mathrm{Bu}$ işlem sonrasında her bir tüpteki süpernatantın 500 $\mu \mathrm{L}$ 'si dikkatlice alınarak içerisinde $400 \mu \mathrm{L}$ izopropanol bulunan 1,5 mL'lik tüplere aktarılmıştır. Çalkalanarak iyice karıştırılan tüpler 14000 devir/d'da 5 d boyunca santrifüj edilmişlerdir. İzolasyonun son aşamasında elde edilen süpernatant tamamen uzaklaştırılarak kalan kat1 kısmın üzerine \%70'lik soğutulmuş etanol eklenmiştir. Tüpler $70^{\circ} \mathrm{C}$ lik su banyosunda $10 \mathrm{~d}$ bekletildikten sonra 14000 devir/d'da 5 d boyunca santrifüj edilmişlerdir. Santrifüjden sonra katı kısımdan kayıp olmamasına özen gösterilerek süpernatant uzaklaştırılmış ve eser miktarda da olsa kalan etanolün uçması için $70^{\circ} \mathrm{C}$ lik su banyosunda 5 d bekletilmiştir. Kurutulan örnek $40 \mu \mathrm{L}$ steril saf su ile süspanse edilmiş ve PCR 
(Polymerase Chain Reaction) için kullanıma hazır hale getirilmiştir.

\section{İzolatların Genetik Tanısı}

İzole edilen küflerin genetik tanıs1, Internal Transcribed Spacer (ITS) bölgesi hedef alınarak gerçekleştirilmiştir. Bölgeye özgü birçok primer bulunmakla beraber en çok kullanılan ITS1 (TCCGTAGGTGAACCTGCGG) ve ITS4 (TCCTCCGCTTATTGATATGC) tercih edilmiştir. PCR karışımı $15 \mu \mathrm{L}$ master mix (Qiagen) 0,5 $\mu$ L ITS1 (ileri) 0,5 $\mu$ L ITS4 (geri) 3 $\mu \mathrm{L}$ kalıp DNA ve $11 \mu \mathrm{L}$ su kullanilarak hazırlanmıştır. Hazırlanan örnekler, $95^{\circ} \mathrm{C}$ 'de $15 \mathrm{~d}$ ilk denatürasyon, bunu takiben 35 döngü olacak şekilde $96^{\circ} \mathrm{C}$ 'de 30 sn denatürasyon, $50^{\circ} \mathrm{C}$ 'de 15 sn bağlanma ve $68^{\circ} \mathrm{C}^{\prime} \mathrm{de} 120$ sn uzama basamakları ve son olarak $72^{\circ} \mathrm{C}$ 'de $10 \mathrm{~d}$ uzama basamağından oluşacak şekilde programlanan PCR thermocycler cihazina (FAVORGEN Peltier Based Thermal Cycler, Model FAPCR 96G) yerleştirilmiştir. Seçilmiş olan programla hedef bölgenin amplifikasyonu gerçekleştirilmiştir (White vd., 1990). PCR işlemi sonucu elde edilen ürün agaroz (Sigma Aldrich) jelde yürütülerek (Thermo Scientific OWL B3) (120 V, $50 \mathrm{~mA}, 150$ d) UV $1 s ̧ 1 \mathrm{k}$ altında kontrol edilmiştir. Yapılan işlemler sonucunda hedeflenen 600 baz çifti uzunluktaki bölgenin amplifiye edilip edilmediği belirlenmiştir. Elde edilen amplikonlar saflaştırilarak sekans analizine tabi tutulmuştur. DNA sekanslama işlemi Kahramanmaraş Sütçü İmam Üniversitesi Üniversite Sanayi Kamu İşbirliği Geliştirme Uygulama ve Araştırma Merkezi (ÜSKİM) Laboratuvarında, hizmet alımı ile ABI 3130 Xl genetic analyzer (Applied Biosystems, Foster City, CA) cihazı kullanılarak gerçekleştirilmiştir. Sekans sonuçları BLAST (BLAST, 2021) algoritmas1 kullanilarak değerlendirilmiştir (Belén Flórez vd., 2007).

\section{BULGULAR ve TARTIŞMA}

Gerçekleştirilen PCR ve agaroz jelde yürütme işlemlerinin ardından 600 baz çifti uzunlukta görülen bantlara ait örnekler sekans analizine tabi tutulmuştur. Marker eşliğinde yürütülen identifikasyona yönelik PCR ürünlerinin jel görüntüleri Şekil 1'de verilmiştir.

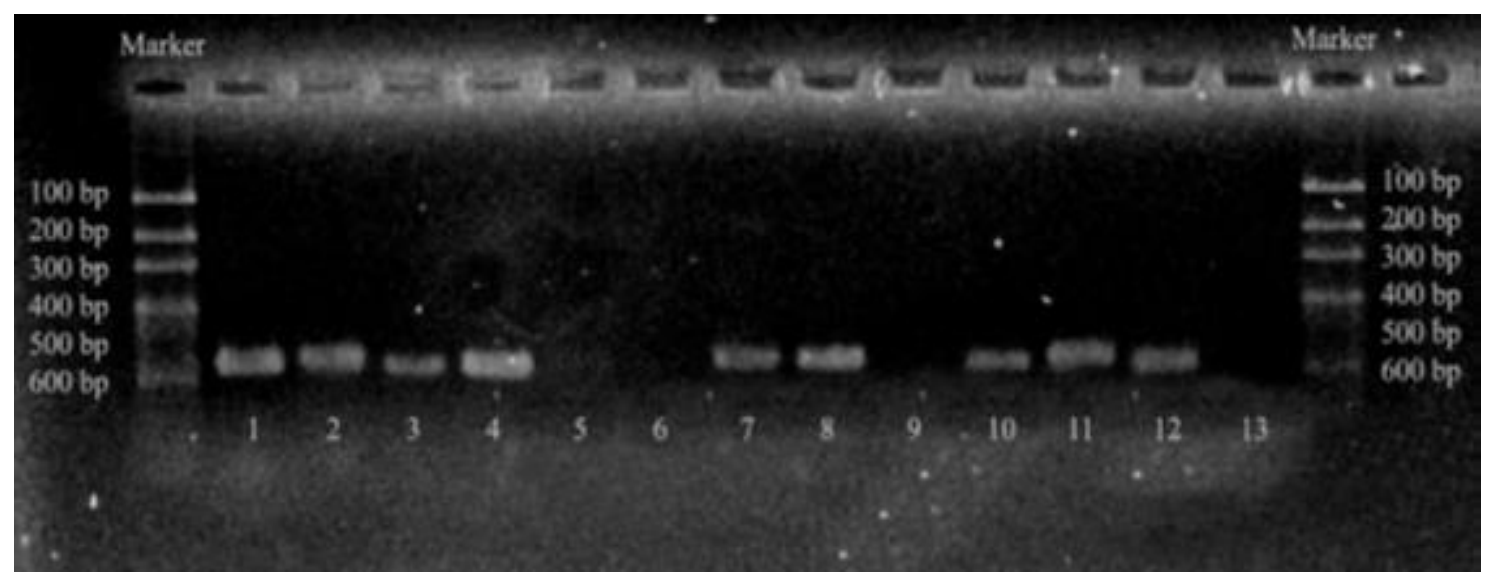

Şekil 1. Sürk peyniri örneklerinden izole edilen küflere ait DNA'ların agaroz jel görüntüsü.

Figure 1. Agarose gel image of the DNA of molds isolated from Surk cheese samples.

Sekans analizleri sonucunda elde edilen gen dizileri Clone Manager Professional Edition (Scientific \& Educational Software) program yardımıyla düzenlenmiştir. Düzenlenen gen dizilerinin, BLAST (BLAST, 2021) algoritmas1 kullanılarak hangi mikroorganizmaya ait oldukları tür düzeyinde tespit edilmiştir.
Piyasadan temin edilen 36 adet Sürk peyniri örneğinden toplam 67 adet küf izolatı elde edilmiştir. Örneklerden elde edilen izolatlarda en fazla bulunan küf türü Penicillium commune olarak tanımlanmıştır. En az bulunan küf türü ise tek bir örnekten izole edilen Bipolaris tetramera olmuștur. 
P. commune, peynirlerde en fazla bozulmaya sebep olan küf türlerinin başında gelmektedir (Taniwaki vd., 2001). Peynir ve diğer süt ürünlerinin üretiminde en çok karşılaşılan problemlerden biri olduğu bildirilmiştir (Lund vd., 2003). Fakat çalışmamızda elde edilen sonuçlara göre olgunlaştırılarak tüketilen Sürk peynirlerinde baskın (\%55.5) olarak bulunan küf türü olduğu söylenebilir. Çakmakçı vd. (2010) ve Hayaloglu ve Kirbag (2007)'ın benzer ürünlerde gerçekleştirmiş oldukları küf tanımlama işlemleri sonucunda $P$. communeye rastlandiğ1 görülmektedir. P. commune, roquefortin ve siklopiazonik asit gibi toksinleri üreten bir tür olmasina rağmen bu toksinleri üretebilmek için bazı optimum şartlara ihtiyaç duymaktadır (Pitt vd., 1986). Bu çalışmada mikotoksin profili incelenmediğinden tanımlanan $P$. commune türünün mikotoksin üretip üretmediği bilinmemektedir. P. commune suşuna ait MEA'daki (25ㄷ-5 gün) koloni morfolojisi Şekil 2'de verilmiştir.
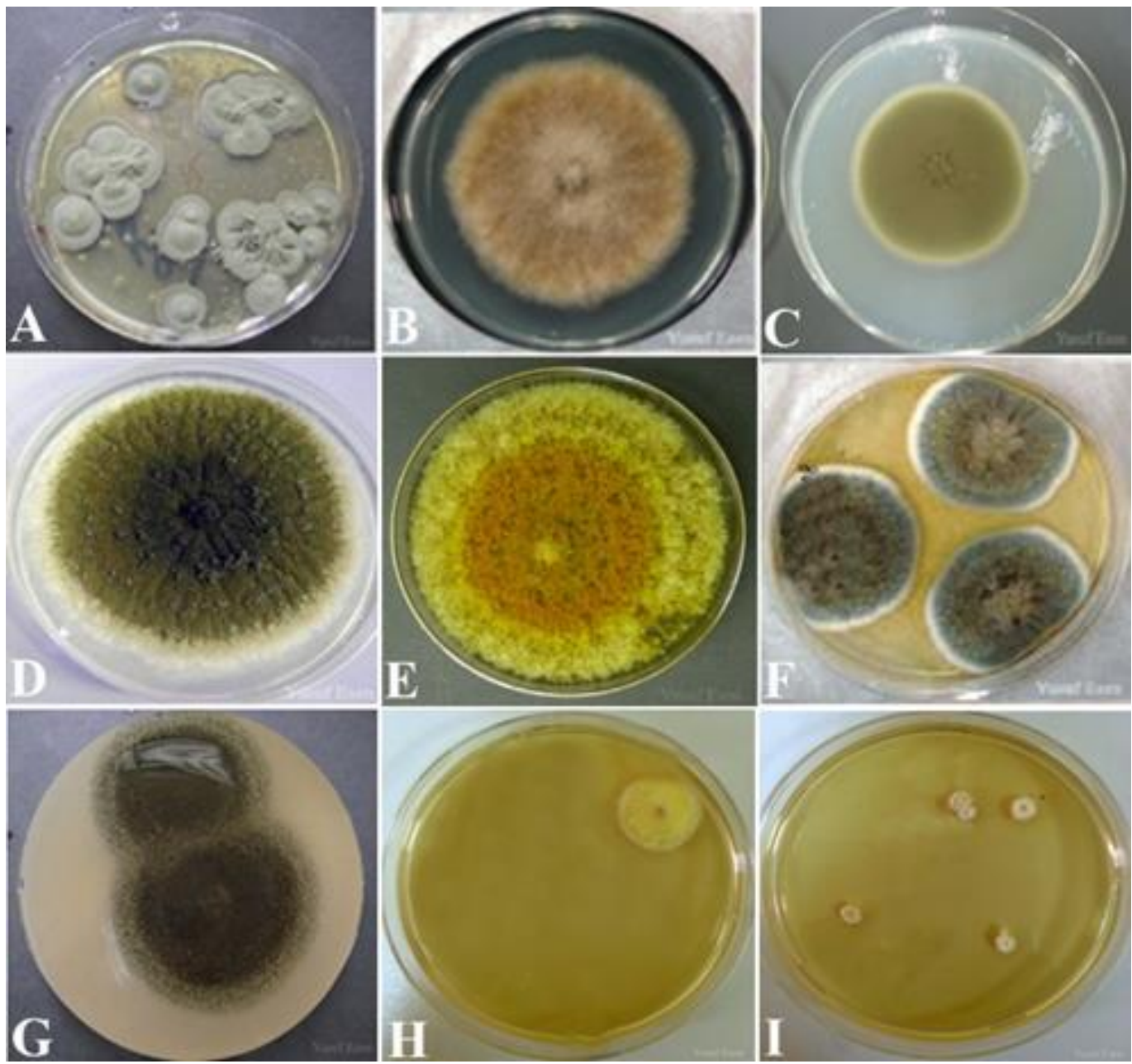

Şekil 2. A: P. commune, B: A. alternata, C: C. cladosporioides, D: A. flavus, E: E. nigrum, F: P. chrysogenum, G: A. niger var. awamori, H: P. sojicola, I: B. tetramera suşlarının MEA ve PDA besiyerlerindeki koloni morfolojileri $\left(25^{\circ} \mathrm{C}^{\prime}\right.$ de 5 gün).

Figure 2. Colony morphology of $A$ : P. commune, B: A. alternata, C: C. cladosporioides, D: A. flavus, E: E. nigrum, F: P. chrysogenum, G: A. niger var. awamori, $H$ : P. sojicola, I: B. tetramera strains on MEA and PDA media (5 days at $25^{\circ} \mathrm{C}$ ) 
Alternaria alternata, P. commune'den sonra Sürk peynirlerinden en fazla örnekten izole edilen küf türüdür (\%33.3). Bir bitki patojeni olup genellikle domateste lekelenmeyle sonuçlanan bazı bitki hastalıklarına sebep olduğu bilinmektedir (Solfrizzo vd., 2005). Daha önce peynir türleriyle ilgili yapılan küf izolasyonu çalışmalarında bu türe hiç rastlanmadığı görülmüştür. Ancak Sürk peynirleriyle ilgili küf tanımlamaya yönelik daha önce yapılmış bir çalışma olmadığından, bu türün varlık sebebi ile ilgili kesin bir kanıya varılamamıştır. Ancak bitkisel kaynaklı olduğu belirtilen bu türün Sürk peyniri bileşimine giren baharat benzeri bitkisel katk1 maddelerinden kontamine olduğu düşünülebilir. Youssef vd., (2021)'nın gerçekleştirmiş olduğu bir çalışmada, A. alternata tarafindan üretilen alternariol monomethyl ether (AME), alternariol $(\mathrm{AOH})$ toksinlerinin insanlarda kansere yakalanma konusunda, özellikle de özafagus (yutak) kanseri açısından çok önemli rol oynadığı ortaya koyulmuştur. A. alternata' nın MEA'daki $\left(25^{\circ} \mathrm{C}-5\right.$ gün) koloni morfolojisi Şekil 2'de verilmiştir.

Örneklerden elde edilmiş olan izolatlar arasında tanımlanan bir başka küf türü ise Cladosporium cladosporioides' tir. Sürk peyniri örneklerinin $\% 30,5$ 'inde bu küf türüne rastlanmıştır. $C$. cladosporioides, bitkilerde hastalı̆ga sebep olan bir küf türüdür (Wang vd., 2013). Bu nedenle örneklere yine baharatlar vasitasiyla kontamine olmuş olabileceği düşünülmektedir. $\mathrm{Bu}$ türün daha önce herhangi bir süt ürününde bulunduğuna dair bir literatür bilgisine rastlanmamıştır. Ancak Sert (1992)'in Erzincan taze tulum peyniri, taze beyaz, taze Civil ve kaşar peynirlerinde gerçekleştirmiş olduğu bir çalışmada aynı cinse ait $C$. herbarum türü tanımlanmıştır.

Bunun yanı sıra, Hayaloglu ve Kirbag (2007) küflü peynirler üzerinde yapmış oldukları bir çalışmada Cladosporium cinsine ait küflerin tanımlandığını bildirmişlerdir. C. cladosporioides türü küfler, kalfostinler olarak bilinen ve protein kinaz C enzimini inhibe eden bir dizi metabolit üretmektedirler. Protein kinaz $\mathrm{C}$ enzimi hücre içi veya hücreler arası sinyal transdüksiyonunda önemli rolü olan bir enzimdir (Kobayashi vd., 2012; Salvatore vd., 2021). Bu enzimin düzgün çalışmaması diyabet, ateroskleroz, otoimmünite, kanser gibi hastalıkların ortaya çıkmasına neden olmaktadır (Basu vd., 2020). Dolayısıyla bu küf türünün örnekler içerisinde toksin oluşturabilecek ortamı bulmuş olma ihtimalinin oldukça kötü sonuçlar doğurabileceği görülmektedir. C. cladosporioides' in PDA'daki $\left(25^{\circ} \mathrm{C}-5\right.$ gün) koloni morfolojisi Şekil 2'de gösterilmiştir.

Epicoccum nigrum ve Aspergillus flavus türleri ise Sürk peyniri örnekleri içerisinde eşit oranda (\%16.6) tanımlanmışlardır. E. nigrum da bir bitki patojenidir (Larena vd., 2005). S. aureus suşlarına karşı antibiyotik aktivite gösterdiği bilinen ve epikorazin A-B gibi bazı antibiyotikler üreten bu türün literatürde insan sağlığını olumsuz etkileyecek bir aktivitesine rastlanmamıştır (Fávaro vd., 2012). A. flavus ise saprofit ve hastalik yapan bir küf türü olmakla birlikte dünyanın her yerinde hemen her üründen izole edilebilmektedir (Bignell, 2010). Spesifik olarak izole edildiği ürünler ise tahillar, kuru baklagiller ve baharatlardır (Ramírez-Camejo vd., 2012). Fakat sağlıklı şartlarda üretilip saklanmayan birçok ürüne olduğu gibi Sürk peynirine de kontamine olmas1, beklenen bir durumdur. A. flavus yüksek patojeniteye sahip aflatoksin çeşitlerini üretebilen bir küf türüdür. Ayrıca sterigmatosistin, siklopiazonik asit, kojik asit, $\beta$-nitropropiyonik asit, aspertoksin, aflatrem, gliotoksin, ve aspergilik asit gibi toksinlerin de üretimini üstlenen bu tür, bahsi geçen toksinlerin birikimlerinden kaynaklanan hastalıklardan dolayı oldukça tehlikeli patojenler sinifina girmektedir (Hedayati vd., 2007). Ancak daha önce de belirtildiği gibi tanımlanan A. flavus suşlarının Sürk peyniri içerisinde toksin üretebilecek ortamı bulup bulamadıkları araştırılmadığından bu ürünün tüketimi konusunda kesin bir yargiya varılamamaktadır. $A$. flavus ve $E$. nigrum'un PDA'daki $\left(25^{\circ} \mathrm{C}-5\right.$ gün $)$ koloni morfolojisi Şekil 2 'de verilmiştir.

Sürk peynirlerinden izole edilen küfler arasında, bulunma oran1 \%13.8 olarak tespit edilen Penicillium chrysogenum, lliman ve subtropikal iklime sahip bölgelerde üretilen ve tüketilen tuzlu gida ürünlerinde yaygın olarak bulunan bir küf türüdür (Samson vd., 2010). Ayrıca kapalı ortamlardan da 
sıklıkla izole edilebilen bir küf türü olduğu bilinmektedir (Andersen vd., 2011). Özkalp (1992)'in Konya küflü peynirinde gerçekleştirmiş olduğu bir çalışmada $P$. chrysogenum türüne ait küflerin $\% 4.73$ oranında izole edildiği bildirilmiştir. Penicillium cinsine ait bu türün nadiren insan sağlığına zarar verdiği hatta penisilin gibi bazı antibiyotiklerin devamlı üreticisi olduğu tespit edilmiştir. Bunların yanı sıra düşük de olsa toksik etkisi olan rokfortin C, meleagrin, chrysogine, xantocillin, sekalonik asit, sorrentanon, sorbisilin ve PR-toksin gibi kimyalları da ürettiği $P$. chrysogenum hakkında yapılmış çalışmalar sonucu elde edilen bilgilerdendir (de Hoog, vd., 2000). Literatür taraması sonucu elde edilen bilgiler 1şığında bu küf türünün Sürk peynirinde bulunmasinin olumlu sonuçlar doğurabileceği söylenebilir. $P$. chrysogenum' un MEA'daki $\left(25^{\circ} \mathrm{C}-5\right.$ gün) koloni morfolojisi Şekil 2'de verilmiştir.

Aspergillus niger var. awamori, Sürk peyniri örneklerinin \%11.1'inde tespit edilmiştir. Sert (1992)'in Erzincan'ın taze tulum peynirleri ile Erzurum'un taze beyaz ve Civil peynirleri üzerinde gerçekleştirmiş olduğu bir çalışmada $A$. niger suşlarının 136 izolattan 1 tanesinde tanımlandığı bilinmektedir. Bu küf türü, bitkilerde siyah küf olarak bilinen bir hastallğa neden olmaktadir (Klich, 2002; Samson vd., 2004). Insanlarda ise diğer Aspergillus türleri kadar olmamakla birlikte, hastalıklara neden olduğu ancak vücuda çok fazla spor alınması durumunda ölümcül olabileceği bildirilmiştir (Varga vd., 2007). A. niger var. awamor' nin PDA'daki $\left(25^{\circ} \mathrm{C}-5\right.$ gün) koloni morfolojisi Şekil 2'de gösterilmiştir.

Sürk peyniri örneklerinden en az oranda izole edilen küf türleri ise Phoma sojicola $(\% 8.3)$ ve Bipolaris tetramera (\%2.7) olmuştur. Nadiren de olsa bitkiler üzerinde, özellikle de soya fasulyesinde patojenite gösteren bir küf olan $P$. sojicola (Ascochyta sojicola) bu etkiyi gösterdiği bitkiler için sıklıkla öldürücü özellik göstermektedir (Kövics vd., 2014). B. tetramera türünün de çok önemli bir bitki patojeni olduğu bildirilmektedir (Manamgoda vd., 2012). Uygun ortam ve sicaklıklarda lipofilik bir toksin olan 6klorodehidrokurvularin üreten $B$. tetramera (Cocbliobolus spicifer), birincil metabolit olarak fitotoksik etkisi olduğu bilinen kurvularin üretmektedir (Dai vd., 2010). Ayrıca bitkilerin gelişmesini destekleyen spicifernin maddesini de üreten bir küf türü olduğu bildirilmektedir (Bender vd., 2009). Bu her iki küf türünün de peynirlerden veya Sürk peyniri benzeri çökelek ürünlerinden daha önce izole edildiğine dair bir bilgiye rastlanmamıştır. P. sojicola'nın $\left(25^{\circ} \mathrm{C}-5\right.$ gün $)$ ve $B$. tetramera'nı $\mathrm{PDA}$ 'daki $\left(25^{\circ} \mathrm{C}-3\right.$ gün) koloni morfolojisi Şekil 2'de verilmiştir.

Tanımlanan küf türleri arasındaki evrimsel ilişkiyi göstermesi amaciyla Clustal (2021) programı kullanılarak filogenetik ağaç oluşturulmuştur. Bu filogenetik ağaç Şekil 3’te gösterilmiştir.

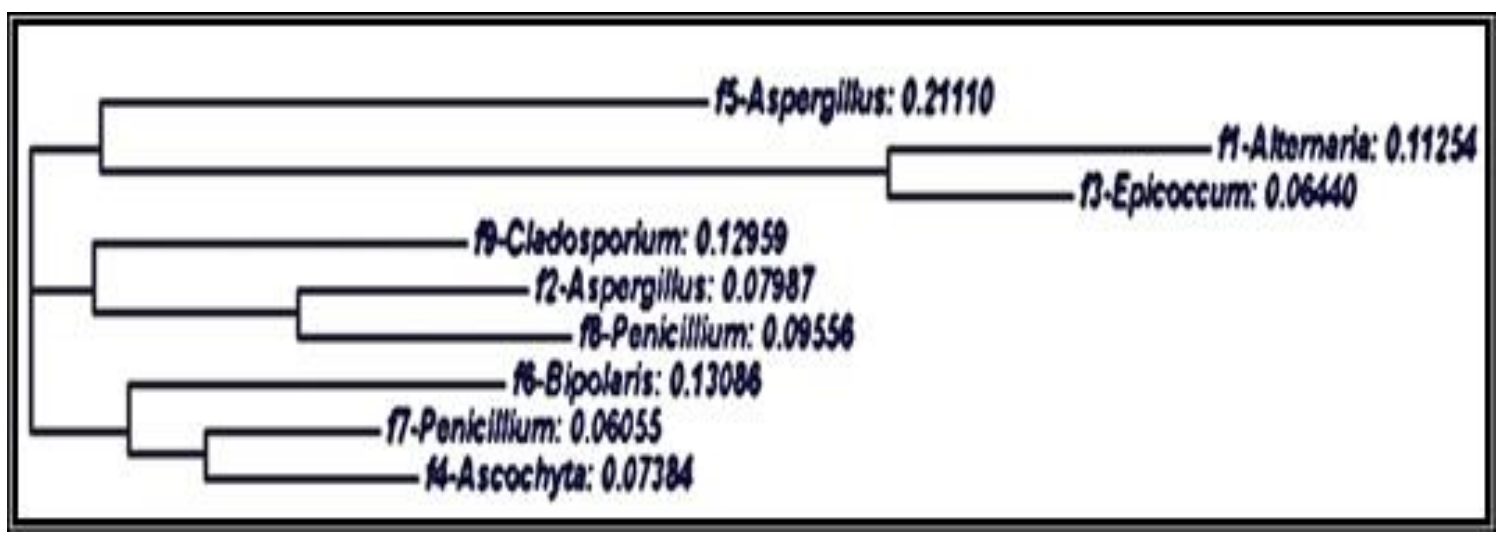

Şekil 3. Tanımlanan türler arasındaki evrimsel ilişkiyi gösteren filogenetik ağaç.

Figure 3. Phylogenetic tree showing the evolutionary relationship between the identified species. 


\section{SONUÇ}

Bu çalışmada, Hatay-Antakya piyasasından temin edilen 36 adet Sürk peyniri örneğinden elde edilen 67 adet küf izolatının genetik identifikasyonu yapılarak sonuçlar literatürden elde edilen bilgiler 1şığında değerlendirilmiştir. Sürk peynirlerinde en fazla bulunan küf türünün Penicillium commune olduğu tespit edilmiştir. İzole edilen tüm küf türleri cins bazında değerlendirildiğinde Penicillium cinsine ait türlerin baskın olduğu görülmektedir. Bitki patojeni oldukları bilinen küflerin, Sürk peynirlerinin bileşimindeki baharat ve otlardan kontamine olduğu düşünülmektedir. İdentifikasyonu yapılan küflerden, gida güvenliği açısından potansiyel olarak olumsuz etki gösterebilecek türler Aspergillus flavus, A. niger var. awamori ve Cladosporium cladosporioides olarak belirlenmiştir. Ayrıca Epicocum nigrum ve Penicillium chrysogenum türlerinin antibiyotik metabolit üretme ihtimalleri sayesinde gelecekte yapilacak çalıșmalarda olumlu yönde kullanılabilecekleri anlaşılmaktadır. Küf mikrobiyotasının çeşitliliği, ürünlerin potansiyel olarak mikotoksin içerebileceğini düşündürmektedir. Bu durumdan dolayı Sürk peynirinin mikotoksin profilinin geniş çaplı bir çalışmayla ortaya koyulması gerekmektedir. Henüz olgunlaştırllmış Sürk peynirlerinin, Aflatoxin M1 dışında mikotoksin içerikleri ile ilgili herhangi bir çalısma yapılmadığından, tüketilebilirlikleri ile ilgili kesin bir yargiya varilamamaktadır. Fakat $A$. alternata ve A. flavus gibi kuvvetli toksin üreticisi olan küf türlerinin varlığından dolayı Sürk peynirinin halk sağlığı açısından dikkatlice incelenmesi gerekmektedir.

\section{TEŞEKKÜR}

Bu çalışmayı 2013/2-1 YLS numaralı proje ile maddi olarak destekleyen Kahramanmaraş Sütçü İmam Üniversitesi Bilimsel Araştırma Projeleri Koordinasyon Birimine teşekkürlerimizi sunarız.

\section{ÇIKAR ÇATIŞMASI BEYANI}

$\mathrm{Bu}$ makalede yer alan yazarların ve kurumların arasında herhangi bir çıkar çatışması bulunmamaktadır.

\section{YAZARLARIN KATKISI}

$\mathrm{Bu}$ çalışmanın danışmanlığı Özlem TURGAY tarafindan yürütülmüş, planlamalar Özlem
TURGAY ve Yusuf ESEN tarafindan gerçekleştirilmiştir. Çalışmanın laboratuvar analizleri Yusuf Esen tarafindan yapılmıştır. Yazarlar makale yazımına katkıda bulunmuş ve Özlem TURGAY son halini inceleyerek onaylamışır.

\section{KAYNAKLAR}

Addas, M. (2013). Syrian Shanklish and Its Quality. Master Dissertation, Mediterranean Agronomic Institute of Chania, Hania, Greek, 51 p.

Andersen, B., Frisvad, J. C., Søndergaard, I., Rasmussen, I. S., Larsen, L. S. (2011). Associations between Fungal Species and WaterDamaged Building Materials. Appl Environ Microbiol 77(12), 4180-4188, doi: 10.1128/ aem.02513-10

Anonymous. (2018). Antakya Küflü Sürk'ü (Çökeleği) Mahreç İşareti Mahreç No: 359. Turkish Patent and Trademark Office. Ankara. https://www.ci.gov.tr/Files/GeographicalSigns/ 359.pdf

Anonymous. (2012). TS ISO 21527-1:2008 Food and animal feed microbiology - horizontal method for counting yeast and molds. Turkish Standards Institution, Ankara

Basu, S., González, B., Li, B., Kimble, G., Kozminski, K. G., Cullen, P. J. (2020). Functions for $\mathrm{Cdc} 42 \mathrm{p}$ BEM adaptors in regulating a differentiation-type MAP kinase pathway. Mol Biol Cell 31(6), 491-510. doi: 10.1091/mbc.E19-080441

Belén Flórez, A., Álvarez-Martín, P., López-Díaz, T. M., Mayo, B. (2007). Morphotypic and molecular identification of filamentous fungi from Spanish blue-veined Cabrales cheese, and typing of Penicillium roqueforti and Geotrichum candidum isolates. Int Dairy J 17(4), 350-357. doi: 10.1016/j.idairyj.2006.04.002.

Bender, C. F., Yoshimoto, F. K., Paradise, C. L., Brabander, J. K. De. (2009). A Concise Synthesis of Berkelic Acid Inspired by Combining the Natural Products Spicifernin and Pulvilloric Acid. J Am Chem Soc 131(32), 11350-11352. doi: 10.1021/ja905387r. 
Bignell, E. (2010). Aspergillus: Molecular Biology and Genomics. By Masayuki Machida and Katsuya Gomi (Eds.). Biotechnology J 5(3), 336-337. doi: 10.1002/biot.201000025.

BLAST. (2021). BLAST Program. https://blast.ncbi.nlm.nih.gov/Blast.cgi?PROG RAM=blastn\&PAGE_TYPE $=$ BlastSearch\&LIN K_LOC=blasthome (Erişim tarihi: 15 Kasım 2021)

Çakmakçı, S., Dağdemir, E., Gürses, M., Çetin, B., Hayaloglu, A. A. (2010). Küflü Civil Peynir Üretimi için Bazı Küflerin İzolasyonu, Tanımlanması, Peynir Üretiminde Kullanılması ve Üretilen Peynirlerin Karakterizasyonu. Tübitak Projesi Sonuç Raporu, Proje No: TOVAG 108O509, Erzurum.

Cantor, M. D., van den Tempel, T., Hansen, T. K., Ardö, Y. (2017). Blue Cheese. In: Cheese: Chemistry, Physics and Microbiology, Fourth Edition, McSweeney, P., L., H., (Chief ed.), Academic Press, UK, pp. 929-954.

Clustal. (2021). Clustal W Program. https://www.ebi.ac.uk/Tools/msa/clustalo/ (Erişim tarihi: 11 Kasım 2021).

Dai, J., Krohn, K., Flörke, U., Pescitelli, G., Kerti, G., Papp, T., Kurtán, T. (2010). Curvularin-Type Metabolites from the Fungus Curvularia sp. Isolated from a Marine Alga. Eur. J. Org. Chem 2010(36), 6928-6937. doi: 10.1002/ ejoc.201001237.

de Hoog, G. S., Guarro, J., Gene, J., Figueras, M. J., Elgart, M. L., (2000). Atlas of Clinical Fungi. Centraalbureauvoor Schimmelcultures, Utrecht, Netherlands, 1126 p.

Delgado, J., Peromingo, B., Núñez, F., Asensio, M. A. (2016). Use of molds and their antifungal proteins for biocontrol of toxigenic molds on dryripened cheese and meats. Curr. Opin. Food Sci. 11, $40-45$.

Domsch, K. H., Gams, W., Anderson, T. H. (1995). Compendium of Soil Fungi, Academic Press, (Vol 1-2) London, UK, 859 p.

Doyle, J. J., Doyle, J. L. (1987). A rapid DNA isolation procedure for small quantities of fresh leaf tissue. Phytochemical Bulletin 19(1), 11-15.
Erdogan, A., Gurses, M., Sert, S. (2003). Isolation of moulds capable of producing mycotoxins from blue mouldy Tulum cheeses produced in Turkey. Int J Food Microbiol 85(1-2), 83-85.

Fávaro, L. C. de L., Sebastianes, F. L. de S., Araújo, W. L. (2012). Epicoccum nigrum P16, a Sugarcane Endophyte, Produces Antifungal Compounds and Induces Root Growth. PLoS ONE 7(6), e36826.

Güler, M. B. (1999). Some studies on the production, the properties and the possibilities of sürk (mouldy coekelek) and carra (pottery) cheese in Hatay region. PhD Dissertation, Çukurova University Institute of Science Food Engineering Department, Adana, Turkey, 160 p.

Hasenekoğlu, İ. (1991). Toprak Mikrofunguslar (7. bask1). Atatürk Üniversitesi, Erzurum, Türkiye, $421 \mathrm{~s}$.

Hayaloglu, A. A., Kirbag, S. (2007). Microbial quality and presence of moulds in Kuflu cheese. Int J Food Microbiol 115(3), 376-380.

Hedayati, M. T., Pasqualotto, A. C., Warn, P. A., Bowyer, P., Denning, D. W. (2007). Aspergillus flavus: human pathogen, allergen and mycotoxin producer. Microbiology 153(6), 1677-1692.

Hegedüs, N., Marx, F. (2013). Antifungal proteins: More than antimicrobials?. Fungal Biol. Rev. 26(4), 132-145.

Klich, M. A. (2002). Identification of Common Aspergillus Species. Centraal Bureau voor Schimmelcultures, Utrecht, Netherlands, 116 p.

Kobayashi, E., Ando, K., Nakano, H., Iida, T., Ohno, H., Morimoto, M., Tamaoki, T. (1989). Calphostins (UCN-1028), novel and specific inhibitors of protein kinase C. I. Fermentation, isolation, physico-chemical properties and biological activities. J. Antibiot. 42(10), 1470-1474.

Kövics, G. J., Sándor, E., Rai, M. K., Irinyi, L. (2014). Phoma-like fungi on soybeans. Crit Rev Microbiol 40(1), 49-62.

Larena, I., Torres, R., De Cal, A., Liñán, M., Melgarejo, P., Domenichini, P., Usall, J. (2005). Biological control of postharvest brown rot 
(Monilinia spp.) of peaches by field applications of Epicoccum nigrum. Biol Control 32(2), 305-310.

Lund, F., Nielsen, A. B., Skouboe, P. (2003). Distribution of Penicillium commune isolates in cheese dairies mapped using secondary metabolite profiles, morphotypes, RAPD and AFLP fingerprinting. Food Microbiol 20(6), 725-734.

Manamgoda, D. S., Cai, L., McKenzie, E. H. C., Crous, P. W., Madrid, H., Chukeatirote, E., Hyde, K. D. (2012). A phylogenetic and taxonomic reevaluation of the Bipolaris - Cocbliobolus - Curvularia Complex. Fungal Divers 56(1), 131-144.

Özkalp, B. (1992). The investigation of mold flora and mycotoxins (B1 B2 G1 G2 and penicillic acid) in mildy cheeses which have been produced in and around of Konya., $\mathrm{PhD}$ Dissertation, Selçuk University Institution of Science Biology Department, Konya, Turkey, $55 \mathrm{p}$.

Patino, E. M., Giorgi, E. J., Mendez, F. Y. (1999). Shanklish cheese - an artisanal product from Corrientes Province, Argentina. Revista Argentina de Lactologia 18, 77-81.

Pitt, J.I., Cruickshank, R. H., Leistner, L. (1986). Penicillium commune, $P$. camembertii, the origin of white cheese moulds, and the production of cyclopiazonic acid. Food Microbiol 3(4), 363-371.

Pitt, John I. (2000). A Laboratory Guide to Common Penicillium Species (3. bask1): Commonwealth Scientific and Industrial Research Organization Division of Food Processing, New South Wales, Australia, 197 p.

Ramírez-Camejo, L. A., Zuluaga-Montero, A., Lázaro-Escudero, M., Hernández-Kendall, V., Bayman, P. (2012). Phylogeography of the cosmopolitan fungus Aspergillus flavus: is everything everywhere? Fungal Biology 116(3), 452-463.

Salvatore, M. M., Andolfi, A., Nicoletti, R. (2021). The Genus Cladosporium: A Rich Source of Diverse and Bioactive Natural Compounds. Molecules 26(13), 3959.

Samson, R.A, Houbraken, J., Thrane, U., Frisvad, J. C., Andersen, B. (2010). Food and Indoor Fungi. Westerdijk Fungal Biodiversity Institute. Utrecht, Netherlands, 481 p.
Samson, Robert A., Houbraken, J. A. M. P., Kuijpers, A. F. A., Frank, J. M., Frisvad, J. C. (2004). New ochratoxin A or sclerotium producing species in Aspergillus section Nigri. Stud Mycol 50, 45-61.

Serhan, M., Mattar, J. (2013). Characterization of four lebanese artisanal goat milk cheeses: Darfiyeh, Aricheh, shankleesh and Serdale by physico-chemical, microbiological and sensory analyses. J Food Agric Environ 11(3-4), 97-101.

Sert, S. (1992). Bazı peynir çeşitlerinde küf florası ve aflatoksin içerikleri ile aflatoksin potansiyellerinin araştırılması: 1. Küf Florası. Atatürk Ü. Zir. Fak. Der. 23(2), 89-100.

Solfrizzo, M., Girolamo, A. De, Vitti, C., Tylkowska, K., Grabarkiewicz-Szczęsna, J., Szopińska, D., Dorna, H. (2005). Toxigenic profile of Alternaria alternata and Alternaria radicina occurring on umbelliferous plants. Food Addit Contam 22(4), 302-308.

Taniwaki, M. ., Hocking, A. ., Pitt, J. ., Fleet, G. (2001). Growth of fungi and mycotoxin production on cheese under modified atmospheres. Int J Food Microbiol 68(1-2), 125133.

Toufeili, I., Shadarevian, S., Artinian, T., Tannous, R. (1995). Ripening changes and sensory properties of bovine, caprine and ovine shankleesh. Int Dairy J 5(2), 179-189.

Varga, J., Kocsubé, S., Tóth, B., Frisvad, J. C., Perrone, G., Susca, A., Samson, R. A. (2007). Aspergillus brasiliensis sp. nov., a biseriate black Aspergillus species with world-wide distribution. Int J Syst Evol Microbiol 57(8), 1925-1932.

Wang, X., Radwan, M. M., Taráwneh, A. H., Gao, J., Wedge, D. E., Rosa, L. H., Cutler, S. J. (2013). Antifungal Activity against Plant Pathogens of Metabolites from the Endophytic Fungus Cladosporium cladosporioides. J Agric Food Chem 61(19), 4551-4555.

White, T. J., Bruns, T., Lee, S., Taylor, J. (1990). Amplification and Direct Sequencing of Fungal Ribosomal RNA Genes for Phylogenetics. In: PCR Protocols, Innis, M., A., (Chief ed.), Academic Press, USA, pp. 315-322. 
Yoltaş, A. (2007). Isolation and identification of fungi in muesli and breakfast cereals on market in and around İzmir. Master Dissertation, Ege University Institution of Science Biology Department, İzmir, Turkey, 249 p.

Youssef, N. H., Qari, S. H., Behiry, S. I., Dessoky, E. S., El-Hallous, E. I., Elshaer, M. M., Heflish,
A. A. (2021). Antimycotoxigenic Activity of Beetroot Extracts against Alternaria alternata Mycotoxins on Potato Crop. Applied Sciences 11(9), 4239. 